\title{
SOME PRESENT-DAY ASPECTS OF CONSERVANCY SYSTEMS.
}

\author{
By PHILIP BOOBBYER, N.D., M.S., M.R.C.S., \\ Medical Officer of Ilealth, Nottingham.
}

(FELLOW.)

Read at Sessional Meeting, Nottingham, November Soth, 190.4.

$B^{\mathrm{r}}$

Iry or conservancy systems of excremont disposal we understand those systems which hicve for their aim and effect the reception of aightsoil into cavities or ressels attached to domestic closets; such nightsoil being remored and varionsly disposed of from time to time, by public or private scavenging. The receptacles in use at the present day are midden pits or lins, and pails of various patterns and sizes, with or without alssorhent ashes, or other material, such for instance, as peat (Goux spotem), sawdust, earth (Moule's closet), charcoal (Stanford's closet).

Viewed from a simply theretical standpoint, these dry systems appear in all respects excellent. Regarded thus, they seem to satisfy alike the essential requirements of decency, sanitation, and scientific economy. Privacy, decency, and cleanliness are secured by proper construction in the first instance, and by subsequent sujervision, and frequent, complete, and car'ful scirenging. Last, but certainly not least in importance, the invaluable fixed nitrogen contained in the dejecta is by these systems conserved for utilization upon the soil as a food for plants. Sir William Crookes, Dr. Vivian Poore, and many other scientists in this country and alroad, have argued strongly on these lines for the continuance and extension of conservancy systems, and it cannot he denied that they have made out (in theory, at least) a strong case in their favour. They have stated, with perfect truth, that the loss of nitrogen available for plant life involved in the destruction or dissipation in water of nightsoil was irreparable. Examples of the successful management of conservancy sristems, together with the extraordinary benefit accruing to local agricultural operations, through the manurial use of dejecta, have been cited 
from regions as wilc apart in space and circumstances as China and Holland. The nightseil is removed in civilised countries, we must remember, by road, rail, and canal, to agricultural districts, and there utilized as manure. The metheshs of removal in uncivilized countries are more primitive, ancl, consequently, in most cases more objectionalule than in the civilizerl. We are told by Dr. Poore and his school that what is possible in all that constitutes the good management of dry closets in Holland and in Hampshire (Andover) is also practicable (for capable people endowed with the power of organisation) in the case of huge cities.

It should not he forgotten, however, that conservancy systems do not commonly secure the preservation of more than a fractional part of the most valuable manurial constituent of nightsoil, the urine. This fact is frequently lost sight of by the apologists of the systems.

Again, the admixture of ashes, silwlust, peat, and other absorlents, together with domestic detritus as various as old umbrellas and biscuit tins, with the nightsoil, which goes on to some extent in most towns and clistricts, entails a large amount of subserfuent screening before the nightsoil can be advantageously ntilized as manure.

The only alternative to dry systems is, of course, water-carriage. Ordinary w.c.'s or well made fresh-water latrines are the best closets, and people must be educated to use them intelligently. That this education can be accomplished with even the lowest (lass of the community is evidenced by the fair condition in which such closets are kept in the slums of cities like Liverpool and Glasgow. I inspected a large number of the poorest tenements in Glasgow with Dr. Chalmers and other gentlemen in July of this year, and found the w.c.'s in every instance in good working order, and much cleaner than I expected. I was told that this comparatively satisfactory condition was due to the fact that each flat has its separate private w.c. for the use of the family or families resident on the flat, that the latter are responsible for its decent maintenance, and that the arrangement on the whole works extremely well. Such an example as this, is, I think, sufficient answer to those who contend that ordinary w.c.'s are inadmissible for the poorest slum property.

With regard to the ultimate disposal of water-'arried sewage, we have (1) discharge into water courses (now practically abandoned) and into the open sea; (2) broad irrigation and downward filtration; (3) bacterial treatment and filtration; (4) chemical treatment and filtration-and combinations of these.

Before proceeding to discuss dry systems, more particularly in the light of modern knowlerge and experience, I may remind you of a few 
historic facts concerning them. In the first place they have a very ancient history, their institution, so far as man is concerned, being coeval with man himself. Loug before the establishment of a regular "cachus" or "jakes" or the use of eloacie, our forbears dug their motions into the soil, as men do still in most uncivilized countries, and as many animals also do. There can be no doubt that the careless management of dry systems in crowded communities led to, or fostered, many of the terrible epidemics of ancient times; and, coming towards modern day's, we find in the letters of Erasmus allusion to the Stygian filth of ordinary human dwellings in the middle ages, the urine of men and animals being often allowed to soak into the floors of living rooms and the ground around the precincts of dwellingrs.

Dr. W. P. Mears and otlue writers have told us of the disastrous results of attempting to carry out the economic disposal of human dejec'tions on a large scale in China, in the paddy fields around large cities; and the filthy licture of the dry closets of our camps during the Sonth African War is fresh in the minds of us all, with the terrible mortalityfrom enteric fever which affected all sections of our army at the front.

A few years ago I wrote a reprort upon "Some Points in Comnection witl Conservancy and Water-Carriage Systems for the Removal of Excreta in Serenty-eight of the Lilrger Towns of Great Britain and Ireland." In this report I was enabled by the courtesy of my colleagnes in oflue towns to give a fairly accurate account of the systems of excreta disposal employed in the great towns of the three kingdoms. I found that some hundreds of thousands of mililen-privies and pail-clesets were in use in these towns, but that except in some half-clozen towns of Torkshire and Lancashire (of which I think Hull was the only one with a population of as much as 100,000) dry closets were condemned, and their conversion to w.c.'s was staterl to he only a matter of time.

The fact that these closets were almost universilly condemmed by medical officers of health and other officials who harl hacl experience of their working on a large scale, and for practically the same reasons in each case, went a long way towards convincing me that in this country at least their days were numbered. It was said of them (a) That they were barbarous and indecent survivals of a less civilized period; $(b)$ That their use was always, but especially during lot and dry weather, detrimental to the liealth of the community; (c) That it was practically impossible with any reasonable outlay to mantain them in decent condition an very poor neighbourhoods; (d) That the satisfactory economic disposal of night-soil in the rural districts outside the towns was an ever-increasing difficulty. 
Each of these comts affords an excellent text for a scparate philippic against these dry closets.

With regard to the first count, their offence against decency, there is much more than a simple sentimental objection to lie urgerl ayainst them. The essence of modern sanitation is cleanliness, and how can cleauliness be effectually inculcarted with such a filtly olject-lesson as the privy-pit or pail continually under the eye and nose? witl air and soil contimually polluterl by foul soakinge and effluvia? with flies and dust in warm weather constantly reminuling the senses that an accumulation of ficcal matter exists in the immediate vicinity of the house? It is often sairl that people can get used to anything. It is true, they can : they can even become so ac'ustomed to filthy surroundings that ther feel no annoyance from them: but if they grow callons to such discomforts as these, it is at the expense of self-respect and a proper sense of decency. It is mainly ly the cultivation of such thonglits prompted by feeling that the poor of our slums must he elerated, and I ramot think of anything, within the official purview at least, more calculated to discourage the cultivation of such finer thonghlts and feelings thim any suggerstion of gratuitous indecency connected with the means of relieving nature.

Now, with regard to the guestion of injury to health. U Jom this point

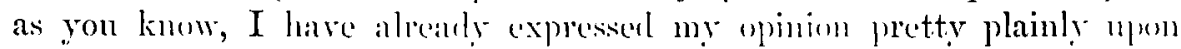
many previous occasions, and I will here only remind you of a few salient facts connected with the question. We know something of the part played by fiecal organisms (e.t., Elererth's typhoid bacillus and the colon group of bacilli) in the prosluetion of disease, and we know thait they abound in the fiecal-polluted air, soil, and structure of these closets.

I have not brought with me any of my oftice spot-maps shewing the incidence of diseise in this city, but you may tike it from me that the enteric fever maps (and in a less degree those for epiclemic diarrlioa) shew a striking correspondence between the distribution of the disease and of the dry closets, especially in the poorer districts.

Agran, it has lieen quite impracticable in some recent past years to gret rid of all our niglt-soil immerliately after collection, and large accumulations have occurred in the city. There is not the slightest cloulst that the incidence of enteric furer was persistently much hearier in the neighbourhoods of these accumulations than elsewhere.

You may say that such storage of night-soil was indicative of mismanagement. It may be so, but under the circumstances the mismanagement was unavoidable, and, with a continuance of our dry system, we should have to stock our night-soil again if we could not get rid of it. And 
further, given a recurrence of the comparatively high temperature and low rainfall of several recent past years, we should certainly have a repetition of our very serious troubles with enteric fever in these years if we failed to send away this class of refuse immediately after collection.

A great deal has been said and written, especially of late, about the action of rats and flies in the propagation of discise, and these pests, under favourable conditions, are among the commonest incidentals of dry closets. I have known many instances, too, in which the infection of enteric ferer has apparently been carried directly by infected closet pails. It must be borne in mind that it is quite impracticable, as a matter of routine, to disinfect the dry-system receptacles, whether pails, pans, or pits.

I shall now say a few words upon the question of how far it is possible for the local authority to secure the decent maintenance (appart altogether from disinfection) of these dry closets in rery poor slum districts. Speaking after considerable experience, I say at once that, without an altogether disproportionate outlay, this is impracticable. Many schemes have been tried for keeping these slum closets in decent order, but all have failed. The explanation probably is, that the ordinary dry closet is such an unsavoury ohject that the very poor will take no pains to minimize the nuisance which, in some degree, is inseparable from its use. Of course I do not say that these closets are responsible for all the filthy habits of the slum denizens. I only contend that there is nothing in this class of closets to encourage the rery poor to cultivate habits of decency and cleanliness in obeying the calls of nature, and that the closets and their surromndings are consequently of ten in a scandalously. filthy condition.

The last point with which $I$ have to deal is the disposal of the nightsoil after collection. It is the ever-growing difficulty of disposing of the nightsoil to farmers and others on reasonable terms, togetler with the also growing objection on the part of residents in districts through which it passes in transit, which have done more to induce local authorities to alsandon dry closets than any of the arguments against them I have previously mentionerl. In many districts it has even become necessary to hurn the nightsoil in order to get rid of it.

The destruction of nightsoil by fire is incleed a "pis aller," which destroys also the only valid argument in favour of dry closets-the argument that their use conserves the fixed nitrogen of fiecal dejections (urine and farces) for the benefit of vegetation.

The number of pail-closets in Nottingham is now about 37.400. The 


\section{ANALYSIS OF RETURNS OF TOWNS IN WHICH THE CONSERVANCY SYSTEMS STILL SURVIVE.}

The following is a list of most of the principal towns in which conservancy systems still survive, to a considerable extent, with their populations, the number of midden-privies and pail-closets in each, and their decennial enteric fever death-rates :-

\begin{tabular}{|c|c|c|c|c|c|c|c|}
\hline Name of 'lown. & $\begin{array}{c}\text { Estimated } \\
\text { Population, } \\
\text { syiuldle of } 1904 .\end{array}$ & & $\begin{array}{l}\text { * Number of } \\
\text { Sidden-Privies }\end{array}$ & & $\begin{array}{l}\text { Number of Pail } \\
\text { and other like } \\
\text { Olusets. }\end{array}$ & & $\begin{array}{l}\text { Ige Annual } \\
\text { arate from } \\
\text { ric Ferer, } \\
3-1902 .\end{array}$ \\
\hline Aston-Minnor & 80,363 & & 10,000 & & 一 & $\cdots$ & 0.21 \\
\hline Belfast & 358 & $\ldots$ & & $\cdots$ & - & . & \\
\hline Birmingham ...... & 537, & . & 11 , & . & 33,000 & 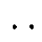 & $0 \cdot 2 \cdot 2$ \\
\hline altom & 175 & $\ldots$ & 14,700 & . & 6,759 & • & $0 \cdot 29$ \\
\hline$\ldots \ldots$ & 28 & & 30,000 & & - & $\cdots$ & $0 \cdot 18$ \\
\hline umber & 100, & $\ldots$ & & .. & 904 & & .23 \\
\hline urton-on-Trent . . & 51, & & & 然 & 4,576 & & $\cdot 14$ \\
\hline 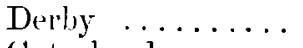 & 120 & & & . & $4,7 \pi 7$ & & 21 \\
\hline head $\ldots .$. & 11 & & & & 10,1 & & 6 \\
\hline$\ldots \ldots$ & 107 & . & & 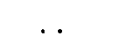 & $1: 3,373$ & $\cdots$ & $0 \cdot 17$ \\
\hline & & & & & $3,-$ & & 0.22 \\
\hline [sifield $\ldots$. & & $\cdots$ & 2,000 & $\cdots$ & $1 \overline{B, 000}$ & $\cdots$ & $\cdot 14$ \\
\hline$\ldots \ldots$ & 258 & . & 47,500 & of all sizes & cs) 100 & . & $1 \cdot 25$ \\
\hline 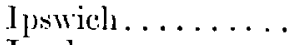 & & . & & . & 90 & . & $0 \cdot 21$ \\
\hline & $4 \bar{x}$ & . & & & $1, \pm$ & 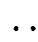 & 0.00 \\
\hline$\cdot \ldots$ & 22 & $\cdots$ & & & $\bar{T}, \mathrm{C}$ & $\cdots$ & $0 \cdot 16$ \\
\hline$\ldots$ & 55 & . & 23 & & 78 & & $0 \cdot 19$ \\
\hline 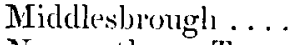 & & & & & 8,1 & & 0.32 \\
\hline e-on-Tyne. & 225 & & 2,900 & & 4,3 & & $0 \cdot 15$ \\
\hline$\ldots \ldots$ & 11 & . & 12,000 & & 3,5 & 0 & 0.22 \\
\hline $1111 \ldots \ldots$ & 24 & . & 500( & (irea) & 40 & & $0 \cdot 30$ \\
\hline$\ldots \ldots$ & & & 76 & & 23,381 & & $0 \cdot 14$ \\
\hline & 11 & & 20,000 & & - & . & 0.31 \\
\hline & & 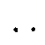 & 120 & & 13,59 & & \\
\hline S & & & 21 & & 6,7 & & 0.45 \\
\hline S & 228 & & & & 8,990 & & 0.35 \\
\hline & 432 & & 20,000 & .. & - & & $0 \cdot 29$ \\
\hline elds .... & & .. & 11,150 & f all sizes & es) - & & \\
\hline & & & & . & - & & $0 \cdot 20$ \\
\hline 1 & & & 0 & & $: 3,00$ & & $0 \cdot 13$ \\
\hline & 67,8 & & $\because 30$ & & 10,506 & & $0 \cdot 17$ \\
\hline wicls. & & & 7,000 & .. & - & & 0.22 \\
\hline & & & 64 & & 8,4 & & 0.5 \\
\hline Wolverhampton & 98, & & - & & $14,0(00$ & & $0 \cdot 29$ \\
\hline York .......... & 81,268 & & 7,787 & $\cdots$ & 61 & & $0 \cdot 24$ \\
\hline
\end{tabular}

A verige annual death-rate from enteric fever (1893-1903)

$$
\text { Do. } \quad \begin{aligned}
\text { in } 33 \text { great towns } & =0 \cdot 20 . \\
\text { London } & =0 \cdot 15 .
\end{aligned}
$$

Pail system in Nottingham.

The majority of these towns contain a larger actual number of privies than Nottingham, but Manchester alone has more pail-closets. Nottingham is peculiar and fortunate in laving so few privies. The pail system was adopted by the Corporation liere in 1868, and from this date onwards the work of conversion was vigorously puslued forward until practically completr.

* There are two privies to one pit in most cunes. 
midden-privies number only about a couple of hundred. The amount of nightsoil annually collected amounts to about 55,000 tons.

With this brief introduction I leare this important subject for discussion, and will only express the hope, in conchusion, that this sessional meeting of The Royal Sanitary Institute may be instrumental in helping on the conversion of our pail-system of excrement disposal to one of water carriage.

The Maror or Notrmginar (Alderman Bright, T.P.) said that, so filr as the city was concerned, they were always, he might say, interested in anything which would promote the health of the inbabitants, and he knew that not only the city of Nottingham but the whole of the Lnited Kingdom was very much indebted to The Royal Sanitary Institute for the numerous schemes they had devised for the improvement of the health of the residents in large towns and cities. He did not pretend to be an expert in any sense in sanitary matters, and he noticed that the title or suliject of Dr. Boobbyer's paper was "Some Present-day Aspects of Conservancy Systems," but he could say that Dr. Boobbyer had rendered very long and very efficient service to the city of Nottingham. He was very enterprising, able, and industrious, and to him Nottingham was indebted in no small degree for the good bealth of the town. It was a very bealthy town, and compared favourably with most cities of similar size in the United Kingdom. The city was naturally well situated, had a rery good fall for its sewage, bad a river running close ly. the ground was largely composed of saudstone, and they had an excellent sewage farm within a distance of three or four miles. Although he had said Dr. Boobbyer was enterprising and able, he was afraid the ratepayers, or at any rate the owners of property, fancied they had some cause of complaint against the Health Department. This was hased on the fact that during the last thirty years there had been no less than three systems of dealing with the night soil. First they had the ash pit, which was, he thought, denominated the midden ("II) to 1868), then they had the pail-closet, and now there was the proposal to have a universal system of water-elosets in the city. There was no doubt whatever that the last-named was the best system, and the one which most tended to the promotion of health. They must, however, bear in mind that the second system having been established at the expense of the owners, it was regarded as hard lines that those owners should have to bear the expense of a third system in order to keep up with the progress of sanitation, especially as they semed to think a fourth system might yet be discovered. He had no douls, therefore, that The Royal Sanitary Institute would have due regard to the pockets of the owner in any proposals they had to make. He was under the impression that watercarriage was the best possible plan in the case of towns neur the sea, and aiso that it would be the most desirable one in the case of inland towns if it were 


\section{Discussion.}

not for the difficulty, in their case, of the disposal of the sewage. Notwithstamding opinions to the contrary, he conld not help thinling that sewage farms in the centre of the country, especially when attached to cities, where manufacturing refuse lad to he deait with, would prove to be only a temporary measure, unless the extent of the land forming the sewage farm wis enomous, hecause when the water-carriage system was introduced in a city like Nottingham the amount of liquid to be deale with must in time be more than could be coped with by the firm. He would only say, in conclusion, that they were delighted to have such a distinguished company hare, and that he hoped their deliberations would result in some practical good. He did not linow whether the members of The Royal Sanitary Institute annually paid a visit to large centres, but if so, he ventured to express the hope that before long Nottinglam might be honoured by another visit from them.

Mr. Cocxcideol Cook (Vice-chairman of Health ('ommittee, Nottingham) said the science of sanitation did not occupy the minds of their forefathers as it did the minds of the present generation, for the simple reason that the population of our cities was very small then compared with what it is now. It was only recently that the population of the country places had begun to pour into the towns in consequence of the establishment of factories, and it was this influx that hat brought the question of sanitary reform to the front. Only a few years ago Nottingham was a comparatively small plice, and privies a few yards from the back-doors of houses were then considered sufficient: but as the population became thicker the question of samitation became more and more pressing. A system of pail-closets was then considered the best thing to adopt, and this system, with the frequent remoral of night-soil, was better than the old privies, which were only emptied once or twice in the fwelve montbs. But now they were getting more enlightened. They found that the pail-closet system was not perfect after all, and that it was desirable that they should adopt improved methods. In his opinion, and in the opinion of the Health Committee, the water-carriage system wis the best. The alteration from pail-clusets to water-closets would be very expensive to property owners, and the question arose as to whether the Corporation would rxpect them to bear the whole expense. There was also the question of the cost of water, which would have to be used extensively, and he thought a diminished 1"ate, or no rate at all, should be charged for th" water used in water-closets. They were very fortunate in Nottingham, as shown by a recent report with regard to their sewage farm, in being able to dispose of all the sewage of the tuwn witbout any difficulty. The ground absorbed all the sewage, and after millions of gallons of liquid had been received by the land, it was found that a few feet below the surface the effluent was so pure as to be almost drinkable. Another question which arose was that of destructors. When he first became interested in the public life of the city of Nottingham, it was a matter of very 


\section{6}

Present-day Aspects of Conservancy Systems.

great surprise to him to see thousands of tons of refuse, collected during many years, lying in large heaps in the town. There was no doubt that enteric fever had arisen close to the refuse heaps, owing to the contamination of the atmosphere in those localities. By the provision of destructors, they had got rid of most of the accumulations, and now destroyed the refuse as it came in, and to aid them in paying the expense they were naking use of the power produced by the burning of the refuse for the production of electricity. They were called a spending committee, but it should be taken into account that they got steam for the generation of electricity when burning the refuse, and he thought they were making rery good use of their opportunities of effecting a saving in this particular instance.

Dr. Dabela (Sheriff of Nottingham) said it was hardly necessary to remind nembers of The Royal Sanitary Institute that epidemic diarrhoa was very different from that caused by eating fruits or other irritants. Epidemic diarrhou had of late years come to be recognised as a totally different disease, as different as typhoid ferer was from typhus fever. He wished to point out one or two peculiarities of this disease of epidemic diarrhwa. It was only prevalent to any extent in the hot summer months; the mortality from the disease was almost entirely confined to cbildren under one year of age; more than half the deaths occurred in cbildren under six montlıs old ; it was seldom seen in the better districts, supplied with a water-carriage system; it rarely occurred amongst infants who were entirely breast-fed : and it occurred mostly in densely occupied districts. Taking into account these considerations, the field of observation was a good deal lessened when they endeavoured to find where the cause of the disease lay. One naturally had to come to the conclusion that the cause lay in the air which these children had to breatlee, and in the food they had to eat. His opinion was that it was largely due to the milk upon which they were fed. He did not say the milk was necessarily impure when it reached the homes, but it became impure afterwards. In lis own practice, when he had insisted upon the milk being kept aseptic, the results bad been better than when this point had not received attention. The latest statistics go a very long way to show that wherever privies or pail-closets exist there is a very ligh infantile death-rate during the third quarter of the year. In proof of this, le would quote the following statistics:--

\begin{tabular}{|c|c|c|c|c|c|}
\hline & & & $\begin{array}{l}\text { Number of } \\
\text { Privies. }\end{array}$ & $\begin{array}{l}\text { Number of } \\
\text { Pails. }\end{array}$ & $\begin{array}{c}\text { Average } \\
\text { Diarrhœa Death-rate for } \\
\text { ten years during the } \\
\text { third quarter (hot }\end{array}$ \\
\hline Birminglıam & & & 11,500 & 33,000 & $3 \cdot 8$ \\
\hline Hull & $\ldots$ & $\ldots$ & 47 & 100 & $4 \cdot 8$ \\
\hline London .. & $\ldots$ & .. & 一 & - & $2 \cdot 4$ \\
\hline Liverpool & . & $\ldots$ & - & -- & $4 \cdot 4$ \\
\hline Nottingham & .. & $\ldots$ & 500 & 40,252 & $3 \cdot 7$ \\
\hline St. Helens & $\ldots$ & $\ldots$ & 5,021 & 6,727 & $4 \cdot 3$ \\
\hline Salford .. & . & .. & 13,983 & 8,990 & $4 \cdot 6$ \\
\hline Sheffield & . & . & 20,700 & - & $4 \cdot 8$ \\
\hline
\end{tabular}


Now it would be very interesting to compare these figur's with those relating to cities, which have an up-to-date water-cal'riage system of excrement removal. He would only refer them to London, where the avorage death-rate during the third quarter of the last ten years had been as low as 204 , and one could not help thinking that there nust be some connection between this epidemic diarlicaa and ther pollution of soil and air caused by privies and pail-closets. It had been said, and to some extent rightly, that infantile diarrhon did not begin unlexs they laad a very hot, dry summer. They certainly got less of it in a wet summer. It stood to reason that these pail-closets caused a great pollution of the soil and air, consisting largely of the bacterium contained in human faces, and it had been shown that when this bacillus was cultivated at about the sime temperature as they found in large towns, and injected into animals, it produced very serere diarrhœa. Dr. J3oobbyer contended that wherrver there were a lot of pail-closets you were sure to get this diarrhoa. If there was this connection between infantile diarrhou and pail-closets, they liad liere a very good reason for altering the system. With their decreasing birth-rate anything that could be done to reduce the infantile death-rate should be done. He did not think the property-owners should bear the whole of the cost of making the alteration; the Corporation should hear some part of it. In Burnley the Health Committere purchased the fittings and said to the owners of property, "If you will put these in we will give them to you," and in that way many closets were converted. That was a plan which he thought was wortly of consideration, and might well be followed in Nottingham. In the case of slums one hesitated whether any large amount should be spent in this direction either by owners or the Corporation. He thought backto-back dwellings should be gradually included in condemned areas, and thit their efforts should, for the time being, be confined to districts inbabited hy decent working men.

Dr. J. R. Kaye (West Riding C.C.) said that in testing the value of any system of conservancy they should have regard to the following considerations:That it should be convenient to the householder for the deposit of excrement; that it did not offend the senses; that it did not pollute the air, soil, or water: that it permitted of the removal of filth with regularity and promptness, and without undue labour ; that it was not expensive and did not occupy too much room; and he thought it was most important that it should be adapted to the class of community it had to serve, whether in city, town, or rural district. It was quite reasonable to say that no method complied so fully with all these requirements as water-carriage and the removal of dry refuse in removable recepticles. It might be said that in connection witb a water-carriage system there must be a good supply of water and a good system of drainage. He said that a proper water supply and a proper system of drainage is necessary for the needs of any population, and that those things are therefore necessary no matter what the conservancy system might be. In the West Riding of Yorkshire a 
large number of water-closets were being provided, and there was an annual reduction of the privy system. In the outlying districts, however, the Local Government Board would not insist upon water-closets if an owner opposed their introduction, but be was anticipating the time when a great many of these privies would be superseded by water-closets, whicb were absolutely necessary in the West Riding, where a number of districts were passing from rural to urban. He was glad to hear the Mayor and one or two other speakers say that in Nottingham they were intending to introduce the water-closet system as far as possible, and even if they had to assist property owners to some extent, they would find there would be an ultimate saring. In onc town which he knew

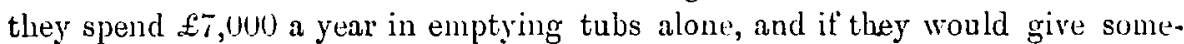
thing to the property owner, or provide w.c. fittings without charge, they would in a few years save the whole of that amount. As sanitarians, they could only have one opinion as to the great number of pails in use in a place like Nottingham, and he heartily agreed with the condemnation of such a system expressed by previous speakers.

Mr. H. Gijbert Wuxart said the ploblem could be divided into two forms as far as towns were concerned. There was the lesser problem in towns, where water-closets were universal, and there was conservancy of dry refuse only. The greater problem existed in towns where water-closets were in a minority, and both nightsoil and dry refuse had to be conserved. Glimsby had, unfortunately, to face the greater problem. They had over 9,500 privy-boxes, and only 4,500 watar-closets; but he was thankful to be able to sily that there rere not twenty-four middens in the town, and so far as he could gather they had never had many. They had but few slums, and uo back-to-back houses. The dry system might be very good in Andovel and other small places. A triend of his, who lived at Iburndale, in Torkshire, provided boxes for the village, and sent his gardener for the nightsoil, which was dug into the garden, and it paid him: but that kind of system was implacticable in towns of from 5,000 to 500,000 inhabitants. The pail system in towns was bad; it was neither satisfactory nor sanitary. They could not help admitting, however, that it was an improvement on the middens, for the excreta were remored more easily, more frequently, and with less nuisance, and there was lesis danger of percolation into the surrounding ground, or of the pollution of hoth soil and air. The feeling of his Council was that it was about time the privy-boxes were abandoned, but there remained the question as to who should bear the expense. He hoped the day of pail-closets would not be a long one, and that water-closets would be adopted, for that sulsstitution would do awny with one of the greatest difficulties with which borough engineer's and scavenging inspectors had to contend. He agreed that the manuria! value of the night-soil was not great, and it was nasty to store, nasty to get to the country districts, and nasty when it got there. 
Mr. A. J. Marisix (London) said he would like to point out that the favour with which the conservancy system had been regarded in many quiluters was based on a mistaken idea as to facts. It was assumed that the whole of the manurial value of the night-soil was retained by a dry system, and that with water-carriage it was lost. The conservancy system, however, was only successtul as regards the solid portion of the dejecta, the manurial value of which was inly one seventh or one eighth of the whole. It was a mistake to assume that by putting the excreta on the land the whole of this ralue could be recorered. liacal matter could only become available as food for plants by decomposition, and it was doubtful whether they got more for the national good by conservancy than by water-carriage. And, after all, the consideration of economy should be a secondary one; the health consideration should come first. With regard to economy, they had to remember that while they knew the direct cost of a grood system of dealing with night-soil or serrige, they did not know the indirect cost of a bad system. Anything which was bad from a health point of view, was bad also from an economic point of view. If the cost of the bad systems, in aroidable illnesses and deaths, was generally known, the work of sanitary reformers would no longer be hampered as it was by lack of public support. There was something absolutely loatlisome in the storage of dejecta near bouses. Food supplies were often kept within in few yards of the excreta, and flies frequently conveyed pollution from the night-soil to the larder. He had no doubt that many mysterious outbreaks of illness could be accounted for in that way. He entirely sympathised with the Mayor of Nottingham in the apprebension which he had expressed on behalf of property owners, who lad already had to install two systems of dealing with excreta, as to the permanence of the third system which was now reconmended. It was rery natural that they should liesitate to adopt anything which was likely to give place to something ilse, lut there could be no doubt that the water-arriage system hild come to stay.

Miss Erans (Nottingham) said that, apart from the practical side of the question, there might be something to be said from the sentimental point of view, which she wis supposed to represent. There must be some consideration for the lives of those poor people who have to we these so-called conveniences, which in Nottingham were anything Jut conveniences. Those of them who had seen a little of the female population here knew how much ther must sufter because of the close proximity of these conveniences to the huses, and the consequent detriment to their efforts at housekeeping. They could not possibly keep their food properly; or teach their children to be clean and observe the rules of health. The people were packed so closely together that one yard, with a convenience common to all, had to serve several families, and in these circumstimces a sense of decency could not exist. If they were to train them to be clean, and therefore to be bealthy, they must give them something better than the present system. 
Mr. C. Masox (Beeston) said he took it that it was simply a matter of the amount of the population of a place as to whether they should have a dry system or water carriage. $\mathrm{He}$ did not see how they were to have al water-carriage system in a very small village. It was a question of erolution, beginning with the system of Moses, then middens, then pail-closets, and then water-carriage, and he thought the last-named method should be adopted throughout the country wherever practicalle. The question of transformation was the one to which attention should be deroted more than ansthing else. That was where the difficulty lay, and the point of cost had not been touched upon to any great extent by the author of the paper. He thought it was not right for a property owner to have to bear the expense of alteration twice in the course of a few years at the dictate of any bealth authority.

Dr. Robertsox (Birmingham) said his first appointment as a medical officer was in a town where dry closets were in existence, and the local authority there had the greatest anxiety with respect to ever recurring outbreaks of typhoid fever. In various parts of the town there were privies, pail-closets, and waterclosets, so that comparative statistics were available for compilation, and the deductions to be drawn from these were absolutely convincing as to the undesirability of the dry system. He was not now able to quote the exact figures, but roughly they showed that the enteric-fever mortality was about five times as great in houses provided with privies, and three times as great in houses provided with pail-closets, as it was in those bouses which had water-closets, whilst the proportionate number of cases of sickness in the former dwellings was even greater. 1[4 had continued to watch that town for many years, and he had found that as the number of water-closets increased the typhoid statistics improred. There could be no cloubt that wherever the storage of filth near dwelling-honses was abolished typhoid was reduced, and a similar effect might be observed with regard to a large number of other diseases. His only concern was that at the present time middens and pail-closets were not being abolished at a sufficiently rapid rate, for his experience in Sheffield and Birmingham was similar to that which he had in the town to which he had already alluded. He would recommend that even in the poorest slum districts water-closets of a first-class description, with really good fittings, should be provided. Inspectors should be employed at the ontset to wo round once a week or fortnight to see that the closets were liept thoroughly clean, and they would find that when once the s!stem had been properly started it would go on successfully. He did not believe that pail-closets were suitable for any large town.

Mr. Courciulor Lrord (Nottingham) said he represented a portion of the slum district of Nottingham, but although the people there might be rough they possessed a great deal of sense. He was pleased to say they bad started sanitary reform there by the introduction of water-closets, and at first they had 
very great trouble. One difficulty was that the landlords said they would raise the rents if water-closets had to be put in; but that had not come off. The people did not know then what these closets were; but if they now took the cpportunity of going round and inspecting them the people would tell them that they were the greatest boon they ever had. They would see that eren the loouses were not kept as clean as these closets. Even in the back-to-back houses and common lodging-houses they were asking how long it would be before they could have the sane system.

Dr. Haxdrord (Nottingham C.C.) said his experience in the County of Nottingham had been unfavourable to these closets. In the country districts they had to contend with many difficulties in connection with the pail-closet sustem of conservancy-difficulties which did not exist in the towns. In many of the districts the water supply was unfortunately too limited to allow of the introduction of a water-carriage system, and that was one of the things to which they must look in the future. He considered that the pail-closet was simply one stage in the development of sanitary progress, but he did not always look upon it as a stage in adrance. In some respects it had been retrogressive. In districts where the local authority were too small to employ their own staft to empty the pails, and a contractor had to be employed, or the adjacent tarmers undertook the duty, the system had proved a retrograde step. It was in matter for regret, too, that when the water supply was abundant the present generation appeared to be content to rely upon the conservancy system. He had little hesitation in saying that the conversion of the dry system into watercarriage was more a question of education than of expense, and in his opinion that education should start in the public elementary schools. They ought not to be content to provide those schools with sanitary arrangements which would just meet the requirements of the sanitary authority. The sanitary arrangements should be models for adoption by the surrounding district, and should be regarded as part of the education in hygiene, for the children in the schools of to-day would be the working people and ratepayers of to-morrow. It was only by means of education that the change to a decent method of removal of excreta would be accomplished. In his judgment this was not merely a question of tub-closets uersus middens or water-closets, but one of cleanliness, decency, and the destruction of rubbish. Rubbish was allowed to accumulate because that had leen the custom. In the most beautiful villages they could hardly see a stream into which broken pots and pans were not thrown. In ancient days that would have been considered a desecration, but now it was a common and growing practice. In small villages the rubbish should be periodically burned by travelling destructors, and he had no doubt that fire would be the great purifier for the coming generation. 
Dr. F. W. Marrix (Brighouse) said that Brighouse, which was a factory town in the West Riding of Yorkshire, had passed through all the different stages of conservancy. Midden privies were followed by pail-closets, and within the last five year's they had had sewerage works established at a cost of $£ 150,000$, and he was pleased to say they were working satisfactorily. Property-owners had gradually been brought to see that the water-carriage system was the best, and he was glad to be able to state that water-closits were now being prorided wherever practicable. The cost of the remoral of the contents of pail-elosets was a very heavy item in the expenditure of any local anthority. This was realised at Brighouse, and it had been decided to provide the water-supply free to one closet in any house, a charge being made for extra closets. The owners of factories were also providing water-closets for the use of their employees, and in these cases the water was paid for by the local authority. He could point with pleasure to the fact that the incidence of enteric fever and diarrhou in Brighouse laad been rery much lessened in the past five years. In 190.0, when the population was roughly 22,000 , there was only one recorded death from diarrhoea. The death-rate of Brighouse last year was slightly under 12 per 1,000 of the population, and he had reason to believe that that result was in a great measure due to the reduction of midden privies and pail-closets.

Dr. Boobbren (Nottingham), sild there was very little for him to say by way of comment on the discussion, as most of the speakers agreed entirely with the statements contained in lis paper. In speaking of the economic disposal of night-soil be was quoting from Dr. Vivian Poore and Sir William Crookes, and referring to the conservation of fixed nitrogen, and not to the protitable sale of the material. He had considered the disposal of night-soil to agriculturists as scarcely more than a side issue in his paper, but had rather expected that it would receive more attention than it had from members of local authorities who were present. The difficulty of dealing satisfactorily with night-soil increased every year. There was never any protit in the undertaking, but the loss was now grenter than ever. At one time farmers would pay a fair price for night-soil decently screened; now it was frequently necessary to pay carriage to the dumping ground in order to get rid of it (by exportation) at all. As to the provision of special pails for the collection of typhoid excreta; - this provision was now made in most linge conservancy centres where cases were nursed at home. It must not be forgotten, however, that cases of enteric fever were seldom reported until they had been some time in progress, and that until the disease was recognised the dejecta would ordinarily find their way into the common priry or pail. 